\title{
The practices and corporate governance frameworks: comparative evidence from south-eastern European countries
}

\author{
Albulena SHALA*, Albana Berisha QEHAJA**
}

\begin{abstract}
Strong corporate governance requires legal, regulatory, and structural frameworks to be relevant and efficient. Poor corporate governance mechanisms, a lack of knowledge of the importance of good corporate governance and, often, a poor institutional structure were major impediments to the growth of effective financial markets and establishment of a stable investment environment in South-Eastern European Countries (SEE). In this paper, we comparatively analyse corporate governance practices and their legal frameworks in SEE countries. The study results show, on the one hand, that Albania has the lowest scores in corporate governance practices and, on the other hand, that Croatia and Slovenia have the highest scores in these practices. Overall, corporate governance is a significant subject for organizations of all sizes and has drawn interest from policy, corporate executives, stakeholders, and academic researchers.
\end{abstract}

Keywords: corporate governance, ownership, boards, South-Eastern Europe (SEE)

\section{Introduction}

Financial intermediation by banks in South-Eastern Europe (hereinafter referred to as SEE), in terms of both scope and structure, has rapidly and significantly evolved in recent years. SEE countries have not given attention to corporate governance concerns while the reform phase in the finance sector could have accelerated.

The challenge of corporate governance development is undoubtedly more powerful in countries in which policy and institutional environments are less

\footnotetext{
* Albulena SHALA is Dr.Sc. and Teaching Assistant at University of Prishtina "Hasan Prishtina”, Prishtina, The Republic of Kosova; e-mail: albulena.shala@uni-pr.edu (ORCID ID: https://orcid.org/0000-0002-8403-4536).

** Albana Berisha QEHAJA is Dr.Sc. and Assistant Professor at Universum College, Prishtina, The Republic of Kosova; e-mail: albana.berisha@universum-ks.org (ORCID ID:https://orcid.org/0000-0002-5001-6073 (corresponding author)).
} 
conducive to the implementation of corporate governance. Bad corporate governance can lead to bank defaults, which may result in real public losses and repercussions due to their possible effect on any existing deposit insurance policies and to the likelihood of wider macroeconomic effects, such as uncertainty danger and effect on payment structures (De Basilea, 2006). SEE has a very high foreign ownership level of the banking system, the stock markets are limited and developing, and almost all banks are closely held. The governance of SEE banks is seen as a crucial feature of their effective integration into the European Union (Cigna and Guy, 2012).

In the SEE region, regulations present business governance issues. While regulation may be considered an additional corporate governance mechanism, in most situations, it reduces the effectiveness of other mechanisms in coping with corporate governance issues. Because of the complexities of the banking industry, the position of boards as a framework for bank corporate governance becomes particularly important in a context of reduced competitiveness, intense regulation, and higher informational asymmetries. Thus, the board has become a key mechanism for monitoring the behaviour of managers and for advising them on identifying and implementing strategies. The bank directors' special knowledge of the complexity of the banking sector enables them to effectively monitor and advise managers.

Accordingly, we are concentrated on governance issues for banks, primarily because of their important role in efficiently allocating capital in an economy and of their crucial importance in SEE's prospects for financial development and economic growth.

This paper seeks to evaluate and compare the legal structure for corporate governance in selected economies (specifically Albania, Bulgaria, Bosnia and Herzegovina, Croatia, Republic of Kosova, North Macedonia, Montenegro, Slovenia, and Serbia), to highlight the progress made so far as well as the shortcomings of the existing framework. Among other things, the contribution of this study is that, unlike in other studies, we have included the Republic of Kosova. Also, such a sample is not included in previous studies.

The paper is divided into five sections. It begins with a brief introduction. The second section contains the related literature review including stylized facts on the banking systems in SEE countries and the challenges of corporate governance in this region. The third section explains the comparative analysis used for this study. The fourth section presents the study results about the legislative framework and the current situation of corporate governance in selected SEE countries. In the final section, the concluding remarks are made.

\section{Literature Review}

Corporate governance is related to how business firms are run; that is, how they are managed and controlled. Corporate governance is important primarily for businesses whose capital is listed on the stock exchange. These firms are 
distinguished by a separation of ownership and management, which poses the wellknown problem of the agency between management and external shareholders (Rosenbaum et al., 2000).

This topic received special attention after the 1998 financial crisis in Russia, Asia, and Brazil (Claessens and Yurtoglu, 2012). Also, during the last decade, corporate governance issues have gradually become significant. The latest financial crisis (2008-2009) served to increase that interest and initiated several new and revised corporate governance guidelines/codes (Gericke, 2018).

In the last 20 years, a significant number of cross-country studies that originate from various corporate governance systems have been conducted. Specifically, the authors found that variations in corporate governance structures raise discrepancies in terms of importance of accounting knowledge (Pervan and Bartulović, 2014). Berglöf and Pajuste (2005) emphasize that the challenges of corporate governance faced by Central and Eastern Europe are similar to those faced by many other emerging markets. Peev and Mueller highlight that:

Although former communist countries are still generally referred to as transition countries, enough time has elapsed since the end of communism to claim that the transition process is, or should be, largely completed, and to assess how well the countries have done achieving growth and transforming themselves into market economies. (2012, p. 371)

As mentioned by Alihodžić (2020), profit for banks is needed to attract new capital and allow the banking sector to expand and boost its efficiency. Profit motivates bank management to optimize and broaden their corporate strategy. Hopt (2013) points out that corporate governance in banks and other financial institutions entities is substantially different from corporate governance in general. The reach of corporate governance for financial institutions stretches outside shareholders (equity governance) to involve bond investors, insurance fund managers, and other investors (bond governance). Hopt (2013) also highlights that the main concern in governance seems to be from the point of view of supervising the debt governance of financial institutions.

The principles of the Organisation for Economic Cooperation and Development (hereinafter often referred to as OECD) define corporate governance as involving a set of relationships between the management of a company, its board, its shareholders, and other interested parties. Corporate governance often includes the mechanism by which the company's priorities are defined, to achieve targets (G20/OECD, 2015). Meanwhile, from a banking sector viewpoint, according to the Basel Committee on Banking Supervision, corporate governance entails the way banks' operations and activities are regulated by their boards of supervisors and senior management, which influences how they:

[...] set the bank's strategy and objectives; select and oversee personnel; operate the bank's business on a day-to-day basis; protect the interests of 
depositors, meet shareholder obligations, and take into account the interests of other recognised stakeholders; align corporate culture, corporate activities and behaviour with the expectation that the bank will operate safely and soundly, with integrity and in compliance with applicable laws and regulations; and establish control functions. (2015, p. 3)

To be successful, the corporate governance legal and regulatory system must be established with a view to the economic environment in which it is to be implemented. According to OECD (2015), good corporate governance implies that shareholders will be able to track and assess their corporate assets through matching market-related facts with the details regarding their opportunities and results. Shareholders, on the other side, find it to be beneficial. They may always use their power to control company behaviour, sell their stock. Meanwhile, investors feel it is beneficial to use their vote to control corporate behaviour, selling their securities (or purchasing new stock), or re-evaluating the assets of a business in their holdings (G20/OECD, 2015). As per Buşu (2015), better corporate governance is not an end in itself. But it is a mean to create confidence in the market and corporate responsibility, which, in turn, is essential for long-term investment enterprises which need access to capital. Governance is relevant for every country, but there are also concerns about the existing corporate governance mechanisms often in nations with an advanced market economy. De Andres and Vallelado (2008) highlight that, given the complexity of the banking business, the role of boards as a mechanism for the corporate governance of banks takes on special relevance in a context of limited competition, intense regulation and higher information asymmetries. According to them, the board is a central tool for tracking the actions of managers and for informing them on the selection and execution of strategies. However, corporate governance in banks plays a special role due to the uniqueness of these financial institutions.

Researches on the corporate governance of banks (e.g., Levine, 2004; Macey and O'Hara, 2003) accept the presence of problems in corporate governance in such organizations, such as complexity and regulation. The corporate governance of banks in developing economies is important for several reasons, in the view of Arun and Turner (2004). First, financial institutions have an increasingly influential role in the developing-economy financial systems and are highly critical drivers of economic development. Second, since capital systems are generally underdeveloped, banks are traditionally the most significant source of financing for the majority of businesses in emerging economies. Third, banks in developed countries are normally the primary depository for the deposits of the country, as well as having a widely agreed means of payments. Fourth, several developed countries have recently liberalized their financial structures by privatizing and by increasing the role of economic control. As a consequence, bank executives in such markets have shown more flexibility in how their banks are managed. Besides that, De Andres and Vallelado (2008) note that the banks' boards play 
a major function in corporate governance, either controlling or guiding executives in the creation and execution of strategies.

\subsection{Stylized facts on the banking systems in SEE countries}

In the SEE area, most local banks are very tiny, although some are listed on the local stock exchanges. Among the SEE countries, they have none of the financial instruments that led to the financial crisis. The following table presents the number of banks in SEE countries overall.

Table 1. Total number of banks in SEE countries

\begin{tabular}{|c|c|c|c|c|c|c|c|c|c|c|c|}
\hline Country/Year & 气̆ & 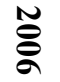 & 气ั & ๕̊̊̆ & ్ֶరి & $\stackrel{\widetilde{\sigma}}{\varrho}$ & $\stackrel{\widetilde{\varrho}}{\Xi}$ & $\stackrel{N}{\stackrel{N}{N}}$ & $\stackrel{\widetilde{\omega}}{\stackrel{\omega}{\omega}}$ & $\underset{\mathscr{E}}{\stackrel{N}{\sigma}}$ & $\stackrel{\text { }}{\stackrel{\tilde{E}}{u}}$ \\
\hline Albania & 16 & 17 & 17 & 16 & 16 & 16 & 16 & 16 & 16 & 16 & 16 \\
\hline Bosnia and Herzegovina (B\&H) & 33 & 32 & 32 & 30 & 30 & $\mathrm{Na}$ & 29 & 28 & 27 & 26 & 26 \\
\hline Bulgaria & 34 & 32 & 29 & 30 & 30 & 31 & 31 & 31 & 30 & 28 & 28 \\
\hline Croatia & 34 & 33 & 33 & 33 & 32 & $\mathrm{Na}$ & 32 & 31 & 30 & 28 & 28 \\
\hline Republic of Kosova & 7 & 6 & 9 & 8 & 8 & 8 & 8 & 9 & 9 & 10 & 10 \\
\hline North Macedonia & 20 & 19 & 18 & 18 & 18 & 18 & 17 & 16 & 16 & 15 & 15 \\
\hline Montenegro & 10 & 10 & 11 & 11 & 11 & 11 & 11 & 11 & 11 & 14 & 14 \\
\hline Serbia & 40 & 37 & 32 & 34 & 34 & 33 & 33 & 32 & 31 & 29 & 31 \\
\hline Slovenia & 25 & 25 & 27 & 24 & 25 & 25 & 25 & 23 & 23 & 21 & 19 \\
\hline
\end{tabular}

Source: Authors' summary using data from World Development Indicators (World Bank WB), Financial Stability Report and Macroeconomic Developments Report (Central Bank of the Republic of Kosova - CBK) and CEE Banking Sector Report June 2017, annually (Raiffeisen Bank Kosova - RBK ${ }^{1}$ ), the period 2005-2015

Over the period 2005-2015, the largest number of banks was dominated by Croatia, Bulgaria, and Serbia. The SEE region started the banking sector reform later than Central and Eastern Europe, but rapid progress has been made in the penetration of foreign banks with a significant increase in the volume of credit to the private sector. As we know, the entry of foreign banks is very important, as they bring modern risk management techniques and knowledge of financial management. Berglöf and Pajuste (2005) point out that the countries of Central and Eastern Europe started their transition from various starting points, and then followed strikingly specific policies.

Foreign ownership predominates in virtually every SEE country. However, the

\footnotetext{
${ }^{1}$ Raffeisen Bank of Kosova (2017), CEE Banking Sector Report, June 2017, annually.
} 
financial market in the Republic of Kosova is distinguished by the existence of mainly international banks. According to the European Bank for Reconstruction and Development (hereinafter often referred to as EBRD) (2016), the reform phase took place differently in each SEE country, but each of them has its own privatization history, a major overhaul of the financial system, and the rapid proliferation of new banking institutions. However, Toçi and Hashi (2013) highlight that some SEE states (Bulgaria, Croatia, Republic of Kosova, and Montenegro) faced severe difficulties in restructuring their financial sector in the early transition years. These countries subsequently sought to establish effective and secure financial structures by enabling international banks to join, based on the assumption that this would lead to a performance increase. Foreign banks (which are, on the average, larger) were more efficient than domestic banks, and the gap has continuously expanded (Toçi and Hashi, 2013). On certain instances, bigger banks have often been shown to be more effective than small banks, even for particular states. The Republic of Kosova's banking system was found to be potentially effective in intermediation compared to other countries but, over time, it has progressed and has a catch-up effect.

Regulation of a large number of privatized banks has moved from state to international ownership in many transition countries. Since privatization, the arrival of international banks had a positive influence on how domestic banks became even more competitive in terms of overhead costs and interest spread, but it did not always have a positive impact on profitability (Alihodžić, 2020). Typically, international banks join the sector by either buying domestic (state or private) institutions, or by developing subsidiaries. During this decade, the foreign ownership rate in the banking sector has continued to have a positive trend in almost all SEE countries. Within these countries, Slovenia is the country where foreign-owned banks have the lowest share of banking sector assets compared to other countries (see the below Table 2).

Creating a strong and sound financial system in SEE has been a fundamental direction in the process of transition to a market economy. Building such a system proved to be very difficult and challenging. The transformation of the banking industry has turned from an unstable sector of economies in transition countries to one of the most advanced sectors which, from time to time, looks far ahead of other sectors that cause certain problems.

The European Bank for Reconstruction and Development (EBRD) published policy indexes in five transportation sectors (electricity, water and sanitation, highways, bridges and telecommunications) and two service sectors (banking and non-bank finance). ${ }^{2}$ The EBRD-produced Banking Sector Reform Index (hereinafter referred to as BSRI), which ranks countries on a scale of 1 to $4+$ based on their success in the banking sector liberalization and institutional change, is included to track the difference in institutional quality across countries. The value of 1 represents very little transformation from a socialist banking industry apart from the divergence

${ }^{2}$ https://www.ebrd.com/transition-indicators-history 
of central banks and commercial banks, whereas a score of $4+$ reflects a rate of restructuring that approximates an industrialized market economy's institutional standards and requirements.

Table 2. Asset share of foreign-owned banks (in \%) in SEE countries

\begin{tabular}{|c|c|c|c|c|c|c|c|c|c|c|c|}
\hline Country/Year & 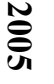 & ชั้ & 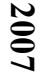 & 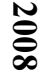 & 용 & $\stackrel{\stackrel{N}{\theta}}{\theta}$ & $\stackrel{\stackrel{N}{g}}{=}$ & 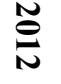 & $\stackrel{\widetilde{\omega}}{\stackrel{\omega}{\omega}}$ & $\stackrel{N}{\stackrel{0}{\theta}}$ & $\stackrel{N}{\varrho}$ \\
\hline Albania & 92 & 91 & 94 & 94 & 92 & 91 & 90 & 90 & 81 & 87 & 86 \\
\hline Bosnia and Herzegovina (B\&H) & 87 & 90 & 91 & 92 & 88 & 89 & 88 & 85 & 86 & 84 & 85 \\
\hline Bulgaria & 76 & 77 & 79 & 82 & 82 & 79 & 73 & 70 & 62 & 76 & 76 \\
\hline Croatia & 92 & 90 & 90 & 90 & 90 & 90 & 90 & 90 & 90 & 90 & 89 \\
\hline Republic of Kosova & 66 & 71 & 77 & 90 & 91 & 90 & 89 & 89 & 89 & 90 & 90 \\
\hline North Macedonia & 54 & 46 & 63 & 69 & 70 & 67 & 65 & 66 & 66 & 69 & 69 \\
\hline Montenegro & 23 & 86 & 83 & 81 & 84 & 100 & 88 & 89 & .. & .. & 79 \\
\hline Serbia & 75 & 86 & 85 & 76 & 74 & 73 & 76 & 74 & 75 & 75 & 76 \\
\hline Slovenia & 25 & 24 & 24 & 26 & 25 & 24 & 24 & 26 & 25 & 35 & 33 \\
\hline
\end{tabular}

Source: Authors' summary using data from World Development Indicators (World Bank WB), Financial Stability Report and Macroeconomic Developments Report (Central Bank of the Republic of Kosova - CBK) and CEE Banking Sector Report June 2017, annually (Raiffeisen Bank Kosova - RBK), the period 2005-2015

Table no. 3 shows that some of the SEE countries had reached a banking sector reform index of 3 or higher, implying that all countries had made significant progress in the development of regulatory and supervisory capacities, that commercial banking activity was substantially liberalized, and that lending to the private sector had increased significantly.

According to the EBRD, the classification was made by 3 means:

Substantial progress in the establishment of bank solvency and of a framework for prudential supervision and regulation; full interest rate liberalization with little preferential access to cheap refinancing; significant lending to private enterprises and significant presence of private banks. (2003, p. 17)

The greatest progress years in the banking sector are 2008-2010 and the period of 2013-2015. During this time, Croatia and Bulgaria are the countries with the highest BSRI, considered by the EBRD as banking systems that almost meet the minimum European Union standards, suggesting that their banking systems are almost as developed as the banking systems in developed countries. 
Table 3. The Banking Sector Reform Index (BSRI) in SEE countries

Country/Year

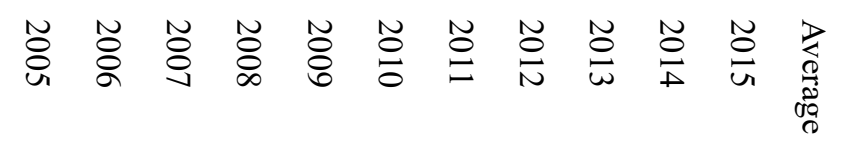

\begin{tabular}{lcccccccccccc}
\hline Albania & 2.7 & 2.7 & 2.7 & 3.0 & 3.0 & 3.0 & 3.0 & 3.0 & 3.0 & 3.0 & 3.0 & 2.92 \\
\hline $\begin{array}{l}\text { Bosnia and Herzegovina } \\
\text { (B\&H) }\end{array}$ & 2.7 & 2.7 & 2.7 & 3.0 & 3.0 & 3.0 & 3.0 & 3.0 & 3.0 & 3.0 & 3.0 & 2.92 \\
\hline Bulgaria & 3.7 & 3.7 & 3.7 & 3.7 & 3.7 & 3.7 & 3.0 & 3.0 & 3.0 & 3.0 & 3.0 & 3.38 \\
\hline Croatia & 4.0 & 4.0 & 4.0 & 4.0 & 4.0 & 4.0 & 3.0 & 3.0 & 3.0 & 3.0 & 3.0 & 3.55 \\
\hline Republic of Kosova &.. &.. &.. &.. &.. &.. &.. &.. & 2 & 2 & 2 & 2.00 \\
\hline North Macedonia & 2.7 & 2.7 & 2.7 & 3.0 & 3.0 & 3.0 & 3.0 & 3.0 & 3.0 & 3.0 & 3.0 & 2.92 \\
\hline Montenegro & 2.3 & 2.7 & 2.7 & 3.0 & 3.0 & 3.0 & 3.0 & 3.0 & 3.0 & 3.0 & 3.0 & 2.88 \\
\hline Serbia & 2.7 & 2.7 & 2.7 & 3.0 & 3.0 & 3.0 & 3.0 & 3.0 & 3.0 & 3.0 & 3.0 & 2.92 \\
\hline Slovenia & 3.3 & 3.3 & 3.3 & 3.3 & 3.3 & 3.3 & 3.0 & 3.0 & 3.0 & 3.0 & 3.0 & 3.16 \\
\hline Average EJL (9) & 2.68 & 2.72 & 2.72 & 2.89 & 2.89 & 2.89 & 2.67 & 2.67 & 2.89 & 2.89 & 2.89
\end{tabular}

Source: Authors' summary using data from Transition Reports (EBRD), the period 2005-2015

Banks are perhaps the most significant financial institutions in most SEE countries, as they can promote economic development. Consequently, as Beju and Ciupac-Ulici (2012) emphasize, many authorities have controlled and limited banking activities over a long period to have a secure and stable banking system. Banks' restraints have taken different forms, including controlling capital flows, interest rates, and credit allocation.

\subsection{Challenges in corporate governance development}

Today, in many countries today, the biggest problem is not so much how to design better laws and regulations for corporate governance, but how to effectively implement them. Many developed countries have too many regulations that prove to be too hard to implement and often contradictory. In turn, adequate regulation raises the question of voluntary versus mandatory approaches and the need for enforcement by both improved regulatory and judicial institutions.

Some continue to see corporate governance as relatively unimportant in developing countries, primarily because of the lack of corporations with traded shares. However, the poor quality of local corporate governance structures is at the core of one of the greatest challenges that most developing countries in the world are presently faced with: how can local economic and political governance systems, including those of corporate governance, be effectively transformed from highly 
personalized and, therefore, based on a system of strong relationships into one based on a rule-based system? (Oman and Blume, 2005).

The challenge of Corporate Governance in transition economies is to generate an environment in which shareholders and managers are encouraged to target longterm performance and to influence the decision-making portfolio of foreign investors. According to Çipi et al. (2014), in transition economies, Corporate Governance's challenge is to create an atmosphere in which shareholders and managers are motivated to target long-term success and to influence foreign investors' decision-making portfolios. Also, Peev (2002) mentions that the regulatory structure for corporate governance must still be considered at an early stage in most countries. While great efforts have been made in institution building, this alone is far from sufficient, especially as it is often used merely to mimic Western models and to mask real processes. Many authors report in detail on the vulnerabilities of the institutional system in various countries in the region, which hinder the enforcement of property rights in terms of corporate governance and allow corruption to flourish (Fox and Heller, 2000; Bloom et al., 2003). According to a report of the World Bank (2015), companies face a variety of corporate governance challenges. Some, such as related-party transactions, insider trading, and other conflicts of interest, require safeguards to prevent them from occurring. Other challenges involve compliance issues and good practices. Also, they mention challenges associated with corporate reporting: the shortage of expertise, the cost of producing information and the complexity of information.

The majority of banks in the region is made up of subsidiaries of multinational banking groups. This can raise unique problems concerning corporate governance. Is it sufficient to enforce the subsidiary management framework of the parent company to comply with the best practices of corporate governance? In all countries, the legal structure carefully specifies the reporting criteria for the Central Bank, but often offers no clarification on information on corporate governance which should otherwise be reported to the public. Arguably, banks should be subject to a higher degree of disclosure because of the systemic significance of banks, especially in those jurisdictions where there is no stock exchange. Banks should have a clear understanding of the rationale behind the requirements of having independent directors and creating board committees. Furthermore, their role, functions and responsibilities should be disclosed in job descriptions for independent directors and by-laws for committees.

To this end, policymakers would need to consider a mechanism for creating a European-level business court that specializes in corporate governance and dispute resolution. These initiatives, aimed at boosting the potential of high-growth companies, may bring Europe closer to its long-held ambition to become the world's most competitive economy. 


\section{Methodology}

This study is based on comparative analysis. As summarized by Azarian:

[...] as a method strategy, comparison plays an important part in the most diverse branches of the humanities and the social sciences alike; and while its early uses can be traced back to the Antiquity, it seems to be more fashionable and evolving than ever, as results from contemporary comparative research can be found in nearly all disciplines and applied to the study of almost any topic, ranging from comparative study of the working conditions across nations, to the analysis of the differences of life values within a single societal context, to the examination of the contrasts of face-work in various cultures, to the study of the varieties of written documents in different countries. (2011, p. 113)

According to Lor (2010), one of the most prominent issues discussed in comparative methodology texts in the social sciences is the question of how many cases should be studied (where cases refer mostly to countries). Thus, he counts three key comparative study designs: single-country studies, many-country (large-N) comparisons, and few-country (small-N) comparisons. Similarly, a three-part classification of comparative research was introduced by Landman (2008) to evaluate multiple countries, several countries, and single-country research. Lor (2010) suggested that we typically ought to pick or combine countries, or both, in comparative studies. He also often discusses critical sample collection problems. The first step in choosing specific countries, according to him, could be to restrict the scope to countries in particular areas or groups, such as democratically governed countries, Islamic countries, or developing countries.

The present analysis takes into account the corporate governance laws and practices of banks in certain jurisdictions in the region. In all SEE countries, the banking sector is comparatively more advanced than the equity markets. Stock markets are illiquid or marked by restricted trading in a vast majority of countries in the region. It follows that, for their financing and growth, companies have to rely on banks. Considering the method used in this study, three stages were followed. In the first stage, the banking sectors of the countries involved were analyzed. In the second stage, the relevant reports to the Central Banks and the legislation in force regarding corporate governance were analyzed, and in the last stage, all data used to highlight which of the countries are more progressive and which are less were analyzed.

As mentioned above, this study is based on comparative analysis. Specifically, it was carried out based on an analysis of relevant literature and databases, such as Central Banks (CB) and journal publications in CBs. Besides this, prudential norms for corporate governance of Albania, Bosnia and Herzegovina (hereinafter referred to at times as "B\&H" for convenience), Bulgaria, Croatia, Republic of Kosova, North Macedonia, Montenegro, Serbia, and Slovenia are taken from publications of Central Banks and European Bank for Reconstruction and Development (EBRD), 
World Bank, etc.

Upon evaluating the prudential legislation of the countries involved and the international standard, a comparative analysis was carried out to conclude on the regulatory framework for SEE corporate governance.

\section{Results and Discussion}

\subsection{Legal framework in corporate governance}

Civil law systems in Continental Europe result in poorer rights of minority shareholders and more centralized control. The transparency of details regarding business is more restricted. Capital markets and corporate system management are less powerful tools for disciplining executives and thus, they have more freedom to use their firm's cash flows as they wish (Mueller and Peev, 2007). Yet, normative entities such as the Basel Committee for Banking Supervision (BCBS), the Financial Stability Board (FSB) and the European Banking Authority (EBA) have made substantial progress in recent years to address the weak corporate governance standards of banks related to the financial crisis.

To safeguard stakeholder rights and strengthen conformity with laws and regulations, as well as the codes of ethics that usually apply to the banking sector, banks are expected to execute their activities based on the standards of effective corporate governance. However, many countries that do nothing to interfere with certain fields continue to place stringent restrictions on the commercial banking market. Meanwhile, the proliferation of universal norms by the Bank for International Settlements (BIS), the International Monetary Fund (IMF), and the World Bank (WB) practically guarantees strong participation by governments in the banking sector (Levine, 2004).

Corporate Governance Standards according to G20/OECD (2015) are:

1. Ensuring the foundations for an efficient governance system for corporations;

2. The rights of shareholders and their complete equality and key ownership functions;

3. Financial markets, investment banks and other intermediaries;

4. The position of the corporate governance interested parties;

5. Disclosure and transparency;

6. The board responsibilities.

The Principles were built with awareness of the fact that corporate governance strategies play a significant part in achieving larger economic priorities in terms of investor interest, capital growth, and distribution. The G20/OECD Corporate Governance Principles assist governments in identifying and strengthening corporate governance's legal, administrative, and structural structure to promote economic performance, balanced development, and financial stability (OECD, 2015).

The Basel Committee on Banking Regulation has released Guidelines: 
Corporate governance principles for banks dated July 2015 (Basel Guidelines, 2015). The main goal of corporate governance will be to sustainably safeguard the rights of creditors in conformity with the public interest on a sustainable basis.

In the Republic of Kosova's banking industry, the law establishes the minimum standards for bank owners, the board of directors, and senior managers regarding their responsibilities in corporate governance $(\mathrm{CBK})^{3}$. According to this regulation, all banks operating in the Republic of Kosova must have the Declaration of Corporate Values and Code of Conduct in writing. The Code of Conduct of a bank shall include rules regarding at least the following matters ${ }^{4}$ :

- Compliance with all laws and regulations applicable in the Republic of Kosova;

- Handling of conflicts of interest;

- External business interests, including investment activities and external employment of board members, management and staff;

- Handling of confidential information;

- Receipt of benefits, gifts, and other favours, etc.

According to this regulation, the board of a bank operating in the Republic of Kosova must select and appoint the senior management of the institution and if necessary, replace it. In the case of branches of foreign banks, this duty belongs to the board of directors of the parent bank ${ }^{5}$.

\subsection{Corporate governance for banks in South-Eastern Europe, legislative framework}

Throughout 2012, with the help of Nestor Advisors, the EBRD established a model for reviewing corporate governance structures and governance processes in the EBRD countries. The evaluation seeks to assess the state of play in the area of corporate governance (status, differences between local laws/regulations and international norms, compliance effectiveness).

The structure for corporate governance in Albania consists primarily of the Law on Businessmen and Commercial Firms, the Law on Formal Auditing, and the Organisation of Certified Chartered Auditors and Licensed Accountants, and the Banks Act. In 2011, a Framework of Corporate Governance was introduced (EBRD, 2017a).

According to EBRD (2017c), corporate governance in B\&H is regulated primarily by the Law on Companies, the Law on Banks and the Law on Accounting and Audit. It's also worth noting that the Securities Commission has released a Joint Stock Company Regulation, as well as many Banking Agency of Federation of

\footnotetext{
${ }^{3}$ Central Bank of Republic of the Kosova (2016), Regulation on Corporate Governance of Banks (retrieved from https://bqk-kos.org/?m=t\&id=213).

4 idem.

5 idem.
} 
Bosnia and Herzegovina Decisions and Guidelines. The Sarajevo Stock Exchange released its own Policy on Corporate Governance in 2009.

On the other hand, Bulgaria has The National Committee in Corporate Governance, made up of economists and business and organization members. Among many other issues, the Committee has the task to oversee the enforcement of the Corporate Governance Code. In 2007, a Bulgarian Regional Corporate Governance Law was adopted, and in 2012 it was revised. The main examples of corporate governance law in Bulgaria include the Securities Public Offering Code, the Accountancy Law, the Credit Institutions Act, the Independent Financial Audit Act, the Commercial Law, and relevant corporate governance rules imposed by the Bulgarian National Bank for listed corporations provided by the Financial Supervisory Commission and for banks (EBRD, 2017b).

The main examples of corporate governance laws in Croatia are provided by the Corporation Statute, the Audit Statute, the Accountancy Act, and the Financial Unions Act. The Croatian Financial Services Supervisory Authority (HANFA) and the Zagreb Stock Exchange introduced a Corporate Governance Framework in 2007 and updated it in 2010 (EBRD, 2017d).

Meanwhile, in North Macedonia, the Macedonian Stock Exchange authorized the Corporate Governance Code in 2006. The central corporate governance regulation in North Macedonia is contained in the Commercial Firms Code, the Equity Code, the Banks Rule, and the Banks Corporate Governance Fundamental Concepts (EBRD, 2017i).

According to EBRD (2017f), Montenegro's key examples of corporate governance regulations include the Business Organizations Law; the Banks Law; the Accounting and Auditing Law; and the Securities Act.

A Corporate Governance Framework was introduced in 2009, seeking to strengthen the corporate governance standards of public corporations. In 2004, the Slovenian Corporate Governance Code for Listed Companies was adopted by the Ljubljana Stock Exchange, the Slovenian Directors' Association, and the Slovenian Managers Association. The Corporations Act, the Banking Act, the Trading of Financial Securities Act and the Auditing Act are the main examples of corporate governance regulations in Slovenia. The Bank of Slovenia and the Ljubljana Stock Exchange have released a series of laws and regulations that are relevant to banks and public firms alike, including corporate governance guidelines as well (ERBD, 2017g). A Code of Corporate Governance has also been in effect in Serbia since 2008. The key examples of corporate governance laws in Serbia are the Corporation Rule, the Banks Regulation, the Accounting Rule, the Auditing Regulation and the Stock Exchange Law (EBRD, 2017h).

A Corporate Governance Code for Publicly Owned Enterprises (POEs) was promulgated in the Republic of Kosova in 2010 and revised in 2014. The key examples of corporate governance laws in the Republic of Kosova are the Law on Business Organizations, the Law on Banks, the Law on Publicly Owned Enterprises, 
and the Law on Accounting, Financial Reporting, and Audit (EBRD, 2017e).

EBRD (2017) classified the corporate governance processes and activities into five main fields for the purpose of assessment: (i) Board structure and functioning; (ii) accountability and transparency of company information; (iii) internal control; (iv) shareholder rights; and (v) owners and entities. The scores indicate the adequacy or the need for change regarding each region and segment of governance. The performance varies from 1 (very weak) to 5 (strong). Then, the evaluation for each segment was computed by combining the subpart ratings: ${ }^{6}$

- Strong to very strong (5) - The corporate governance structure/related business policies are acceptable and compatible with best practices.

- Moderately strong (4) - Most of the corporate governance framework/related activities are fit for their purpose, although certain areas need more change.

- Fair (3) - There are several aspects of professional exercise in the corporate governance framework/related activities of corporations; however, there are a few important concerns that indicate that the overall structure will be reviewed with a vision to change.

- Weak (2) - The corporate governance structure/associated business practices include some principles of quality practice; however, ultimately, further reform is needed in some aspects.

- Very weak (1) - The corporate governance structure/related business policies pose major challenges and the system requires drastic change.

According to the EBRD (2017a) in Legislation and Practices for Corporate Governance, Albania has the lowest scores compared with other countries in the region (Table no. 6; Figure 1).

Table 6. Corporate governance legislation and practices in SEE countries

\begin{tabular}{lccccccccc}
\hline $\begin{array}{c}\text { Corporate governance } \\
\text { framework and practices }\end{array}$ & $\mathrm{AL}$ & $\mathrm{B} \& \mathrm{H}$ & $\mathrm{BU}$ & $\mathrm{CR}$ & $\mathrm{MA}$ & $\mathrm{MO}$ & $\mathrm{SE}$ & $\mathrm{SL}$ & $\mathrm{KS}$ \\
\hline $\begin{array}{l}\text { Structure and functioning of the } \\
\text { board }\end{array}$ & 2 & 2 & 2 & $2 / 3$ & 2 & $2 / 3$ & 3 & 3 & $3 / 2$ \\
\hline Transparency and disclosure & 2 & 3 & $3 / 4$ & 4 & 3 & 3 & 4 & 4 & 3 \\
\hline Internal control & 2 & 2 & $2 / 3$ & 3 & 3 & 3 & 3 & 3 & 3 \\
\hline Rights of shareholders & 3 & $3 / 4$ & 4 & 4 & 4 & $3 / 4$ & $3 / 4$ & $3 / 4$ & 3 \\
\hline Stakeholders and institutions & 2 & 2 & $2 / 3$ & 4 & 2 & 2 & 2 & 4 & $3 / 2$ \\
\hline
\end{tabular}

Note: very weak - 1; weak - 2; fair - 3; moderately strong - 4; strong to very strong - 5 .

Source: Authors' summary using data from EBRD - Corporate governance in transition economies: Individual country reports (2017a, 2017b, 2017c, 2017d, 2017e, 2017i, 2017f, 2017g, 2017h)

${ }^{6}$ Corporate Governance Sector Assessment (retrieved from https://www.ebrd.com/). 
Figure 1. Corporate governance legislation and practices in SEE countries

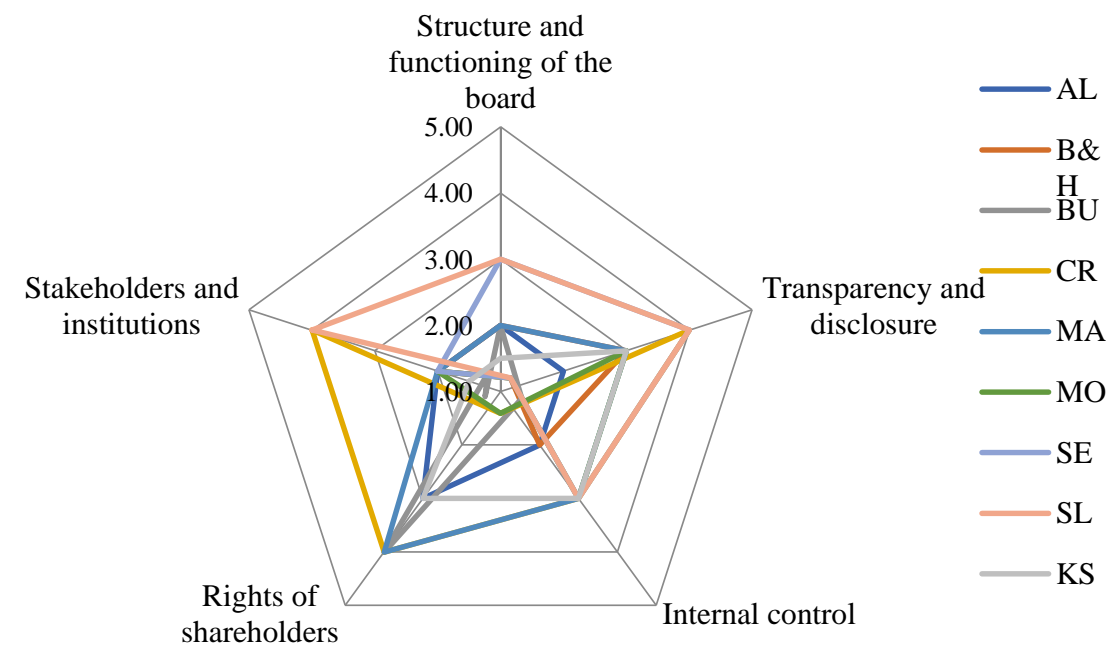

Source: Authors' summary using data from EBRD - Corporate governance in transition economies: Individual country reports (2017a, 2017b, 2017c, 2017d, 2017e, 2017i, 2017f, 2017g, 2017h)

\subsection{Structure and functioning of the board}

As explained by EBRD (2017c), banks in Bosnia and Herzegovina are obliged to set up audit boards, with representatives named by the supervisory board but again, audit boards cannot comprise supervisory board members. Equally, there are certification criteria for board members in Bulgaria only for banks. Meanwhile, in Croatia, only in banks, the law requires boards to have at least one independent director, and only one of the ten biggest companies (a bank) discloses having one but only one - independent director on the committee. On the other side, in the case of banks in Montenegro, boards are expected to comprise at least two people who are "neutral from the bank" but the criteria which determine their independence could be more comprehensive (EBRD, 2017f). Also, according to EBRD (2017g), banks in Slovenia are required to create risk committees and, depending on their length, nomination and remuneration committees. In Serbia, only banks and financial institutions have board membership qualification criteria (EBRD, 2017h). In the Republic of Kosova, boards tend to be fairly tiny with six members reflecting the average board capacity. Diversity in gender continues to be restricted at this level. The audit committee of banks tends to be made up of several non-executive board 
members and includes at least one "outsider" (i.e., non-management member) who has expertise in accounting or auditing (EBRD, 2017e).

Table 7. Structure and functioning of the board in SEE countries

\begin{tabular}{lccccccccc}
\hline \multicolumn{1}{c}{$\begin{array}{c}\text { Key areas and } \\
\text { rating }\end{array}$} & ALB & B\&H & BU & CR & MA & MO & SE & SL & KS \\
\hline Board composition & 2 & 2 & 2 & $2 / 3$ & 3 & 2 & 3 & 3 & 3 \\
\hline $\begin{array}{l}\text { Gender diversity at } \\
\text { the board }\end{array}$ & 1 & 2 & 2 & 3 & 3 & 3 & 4 & 4 & 2 \\
\hline $\begin{array}{l}\text { Independent } \\
\text { directors }\end{array}$ & 1 & 1 & 2 & 2 & 3 & 1 & 3 & 3 & 1 \\
\hline Board effectiveness & 1 & 1 & 2 & 2 & 2 & 2 & 3 & 3 & 2 \\
\hline $\begin{array}{l}\text { Responsibilities of } \\
\text { the board }\end{array}$ & 3 & 3 & 3 & 3 & 3 & 3 & 3 & 3 & 3 \\
\hline
\end{tabular}

Note: very weak - 1; weak - 2; fair - 3; moderately strong - 4; strong to very strong - 5 .

Source: Authors' summary using data from EBRD - Corporate governance in transition economies: Individual country reports (2017a, 2017b, 2017c, 2017d, 2017e, 2017i, 2017f, 2017g, 2017h)

In all countries, boards are generally small and display gender diversity. Albania has the lowest average for diversity in southeast Europe. The board's female representation among the top ten listed firms in Slovenia is above 20\%, one of the strongest in the EBRD region. In Serbia, too, gender equality is among the strongest in the EBRD area in the boards of the ten largest listed firms (see the below figure).

Figure 2. Comparison of gender diversity at the board in SEE countries

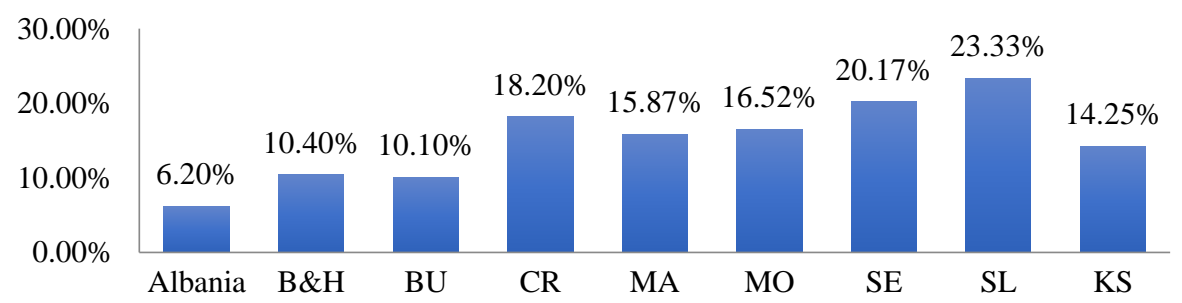

Source: Authors' summary using data from EBRD - Corporate governance in transition economies: Individual country reports (2017a, 2017b, 2017c, 2017d, 2017e, 2017i, 2017f, 2017g, 2017h)

Overall, Albania has the smallest scores compared with other countries for the structure and functioning of the board (Table no. 7). The boards in Albania are relatively small. Evidence has also shown that smaller boards continue to work stronger, given the required combination of expertise and resources in place. However, according to EBRD (2017a), this does not seem to be the case in Albania. 
It was not possible to assess if boards have a diversified mix of skills as no company discloses the board members' qualifications.

\section{Table 8. Board structures of SEE banks}

\begin{tabular}{lcc}
\hline Country & Structure of board & $\begin{array}{c}\text { A corporate } \\
\text { governance code }\end{array}$ \\
\hline Albania (AL) & Two-tier & Yes (2011) \\
\hline Bosnia and Herzegovina (B\&H) & Two-tier & Yes (2009) \\
\hline Bulgaria (BU) & $\begin{array}{c}\text { Option to choose one-tier } \\
\text { or two-tier }\end{array}$ & Yes $(2007)$ \\
\hline Croatia (CR) & Two-tier & Yes (2007) \\
\hline N. Macedonia (MA) & Two-tier & Yes (2006) \\
\hline Montenegro (MO) & One-tier & Yes (2007) \\
\hline Slovenia (SL) & Two-tier & Yes (2004) \\
\hline Serbia (SE) & Two-tier & Yes $(2008)$ \\
\hline Republic of Kosova (RKS) & Two-tier & Yes $(2014)$
\end{tabular}

Note: In the tables and figures below, the abbreviations of countries are used for convenience. Source: Authors' summary using data from EBRD - Corporate governance in transition economies: Individual country reports (2017a, 2017b, 2017c, 2017d, 2017e, 2017i, 2017f, 2017g, 2017h) and World Bank - Corporate governance for banks in Southeast Europe (2012)

Banks ought to be mindful of the distinctions between the operational and board committees and therefore, some clarity is still required in legislation, policy, and procedure (Cigna and Guy, 2012). The expertise and experience of members of the board of banks and other financial organizations is even more essential than freedom while getting a range of independent directors is helpful.

Thus, according to Cigna and Guy (2012), most nations in the area have twotier board systems (supervisory board and management board), with two nations having banks to select from, and one nation (Montenegro) requiring a single-tier board (see Table no. 8).

\subsection{Transparency and disclosure}

However, according to the ERBD Report (2017), both states file and publish their International Financial Reporting Standards (hereinafter referred to as IFRS) - compliant financial statements. Market and shareholder disclosure are governed by statute, which appears to be well applied. Joint-stock businesses are expected to have an impartial external auditor evaluate their financial records and publish the auditor's analysis.

According to ERBD (2017a) in Albania, the regulation allows major businesses and banks to file and report their financial statements following IFRS, but it seems that this obligation is fulfilled mainly by the three banks of the ten biggest firms. The legislation needs corporations and banks to have an impartial external auditor and to 
report their identity, but it is not obvious who is liable for the "independence test". Reporting to the markets and shareholders also appears to be controlled in detail in Bosnia and Herzegovina, but in practice, the availability of information is limited (EBRD, 2017c). In Croatia, businesses are expected to publish their financial statements and this obligation seems to be well fulfilled by the largest listed firms. Although the quality of non-financial details appears relatively strong, the main information is not accessible (e.g., board members' selection, events and timing of board and committee meetings, and the structure of committees) (EBRD, 2017d).

Table 9. Transparency and disclosure in SEE countries

\begin{tabular}{lccccccccc}
\hline Key areas and rating & AL & B\&H & BU & CR & MA & MO & SE & SL & KS \\
\hline $\begin{array}{l}\text { Non-financial information } \\
\text { disclosure }\end{array}$ & 2 & 2 & 3 & 4 & 2 & 2 & 3 & $3 / 4$ & 3 \\
\hline $\begin{array}{l}\text { Financial information } \\
\text { disclosure }\end{array}$ & 2 & 4 & 5 & 5 & 3 & 5 & 5 & 4 & 5 \\
\hline $\begin{array}{l}\text { Reporting to the market } \\
\text { and to shareholders }\end{array}$ & 2 & 2 & 3 & 4 & 2 & 3 & $3 / 4$ & 4 & 3 \\
\hline $\begin{array}{l}\text { Disclosure on the external } \\
\text { audit }\end{array}$ & 2 & 3 & 4 & 4 & 3 & 4 & 4 & 4 & 3 \\
\hline
\end{tabular}

Note: very weak - 1; weak - 2; fair - 3; moderately strong - 4; strong to very strong - 5 .

Source: Authors' summary using data from EBRD - Corporate governance in transition economies: Individual country reports (2017a 2017b, 2017c, 2017d, 2017e, 2017i, 2017f, 2017g, 2017h)

Figure 3. Transparency and disclosure in SEE countries

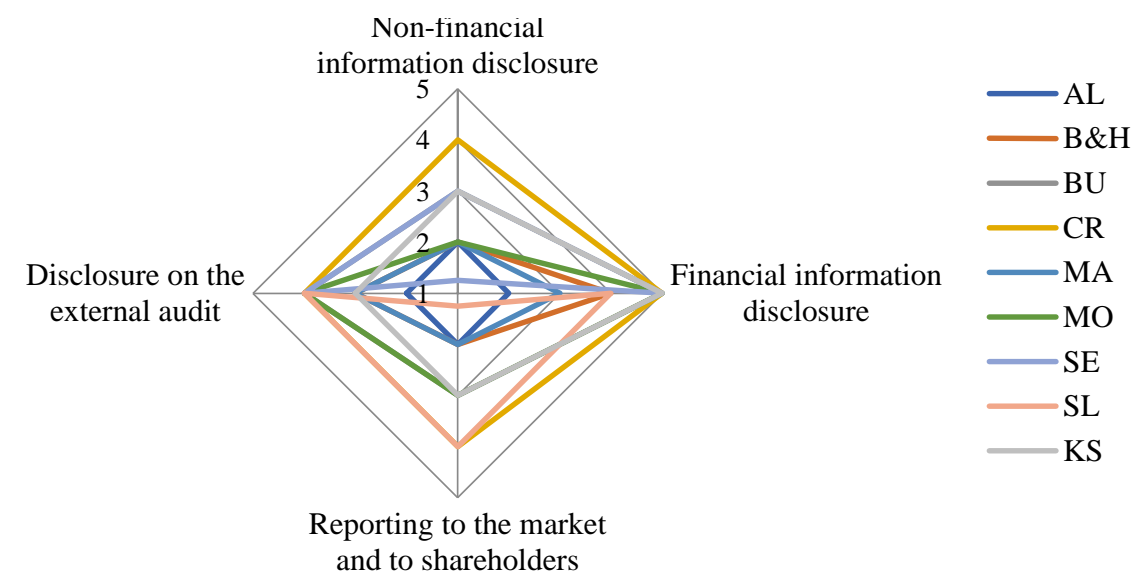

Source: Authors' summary using data from EBRD - Corporate governance in transition economies: Individual country reports (2017a 2017b, 2017c, 2017d, 2017e, 2017i, 2017f, 2017g, 2017h) 
Banks and Public Owned Enterprises (POEs) in the Republic of Kosova are required to release their financial reports online which will provide financial and non-financial details (EBRD, 2017e). This requirement appears to be implemented, but the content of non-financial knowledge has room for improvement. Financial reports will be compiled in compliance with IFRS and the large majority of the largest companies appear to comply. Banks, large and medium-sized companies, and POEs are expected to hire an impartial external auditor and the overwhelming majority of the larger businesses tend to be compliant with this.

\subsection{Internal control}

Listed corporations and institutions in all countries are expected to provide an external independent audit. Besides, public firms and banks ought to establish an internal management structure. The internal management structure is not welldeveloped in Albania. The external audit is only necessary for banks, but even three of the ten biggest banks report by getting an audit committee in place. There is no tendency to have "board" committees in all situations, these are mostly made by outsiders i.e., non-board members i.e., outsiders (EBRD, 2017a).

According to EBRD (2017), banks are expected to change the external auditor (partner) after 7 years, but because the auditor's report is most frequently signed with the firm's name and not with the auditor's name conducting the audit, it is not feasible in practice to know whether an audit partner rotates. As per EBRD (2017c), an internal audit feature is needed in $\mathrm{B} \& \mathrm{H}$ companies with securities admitted to trading; however, it is not clear whether they have it in place or not because transparency on this point is restricted. Financial institutions do not appear to have to establish a standalone compliance function.

Only two out of the ten biggest listed firms in Bulgaria - both banks - disclose having internal audit mechanisms in place (EBRD, 2017b). Listed businesses and banks are expected to set up an audit board; however, it is not completely clear whether audit boards are autonomous, eligible and successful (EBRD, 2017). External auditors in Macedonia are required to rotate regularly, while there are no similar requirements for audit firms (EBRD, 2017i). Banks in Slovenia are obligated to have an audit committee composed of members of the supervisory board. In firms, the law requires that at least one audit member of the committee be an independent accounting and auditing expert. This requirement tends to be interpreted as implying that the "independent expert" will not be a director (supervisory) of the board (EBRD, 2017g).

In the Republic of Kosova, banks and POEs are required to set up an internal audit department reporting to the audit committee and most of the biggest corporations appear to be complying with it. Banks are not expressly mandated to provide a separate enforcement feature. Banks and POEs are expected to set up audit committees and eight out of ten largest organizations claimed to have set up one. The audit committee 
can only include board members in POEs. At least one non-board member must be a member of the audit committee in banks - with auditing qualification.

\section{Table 10. Internal control in SEE countries}

\begin{tabular}{lllllllllll}
\hline \multicolumn{1}{c}{ Key areas and rating } & AL & B\&H & BU & CR & MA & MO & SE & SL & KS \\
\hline $\begin{array}{l}\text { Quality within the framework } \\
\text { of internal control }\end{array}$ & 2 & 2 & 2 & 3 & 3 & 3 & 3 & 3 & 3 \\
\hline $\begin{array}{l}\text { Internal and external } \\
\text { consistency reviews }\end{array}$ & 2 & 3 & 3 & 4 & 4 & 3 & 4 & 4 & 4 \\
\hline $\begin{array}{l}\text { Audit group working and } \\
\text { freedom }\end{array}$ & 2 & 2 & 2 & 2 & 2 & 2 & $2 / 3$ & 3 & 2 \\
\hline $\begin{array}{l}\text { Control over related party } \\
\text { transactions and conflict of } \\
\text { interest }\end{array}$ & 3 & 2 & 4 & 3 & 4 & $3 / 4$ & 4 & 3 & 3 \\
\hline
\end{tabular}

Note: very weak - 1; weak - 2; fair - 3; moderately strong - 4; strong to very strong - 5 .

Source: Authors' summary using data from EBRD - Corporate governance in transition economies: Individual country reports (2017a, 2017b, 2017c, 2017d, 2017e, 2017i, 2017f, 2017g, 2017h)

\section{Figure 4. Internal control in SEE countries}

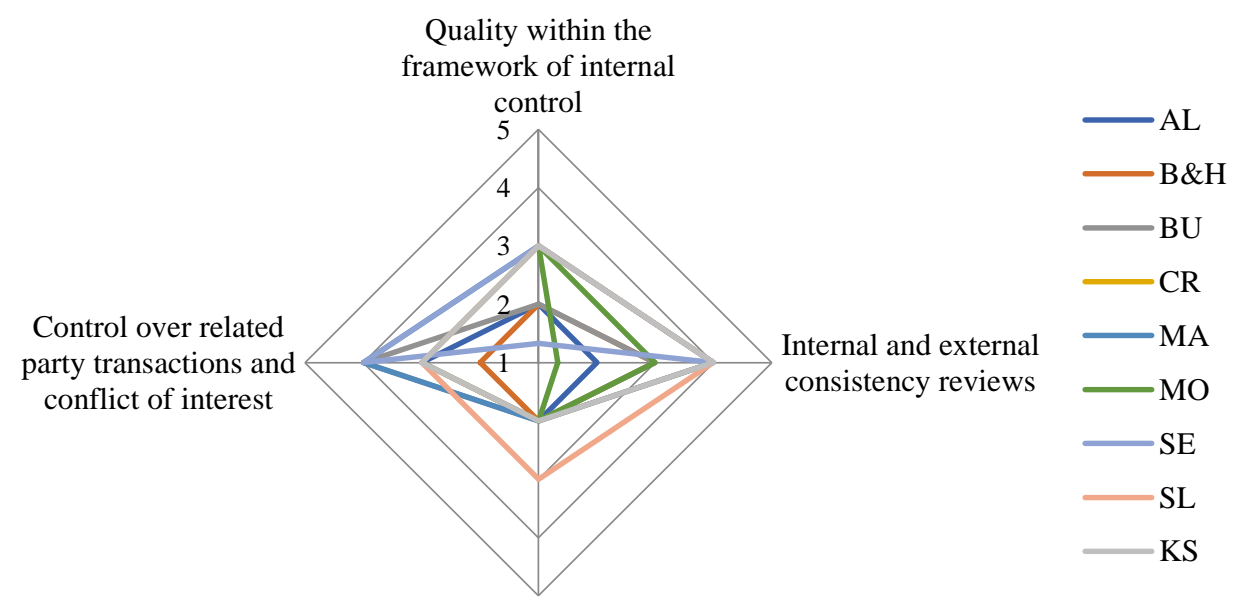

Audit group working and freedom

Source: Source: Authors' summary using data from EBRD - Corporate governance in transition economies: Individual country reports (2017a, 2017b, 2017c, 2017d, 2017e, 2017i, 2017f, 2017g, 2017h) 
There is no requirement that the audit committee should be made up of fully trained unbiased board members. External auditors are not permitted to offer nonauditing services to the banks and POEs. In banks, CBK may involve the rotation of auditors. Related party transactions are only controlled in respect of banks.

\subsection{Rights of shareholders}

Shareholders have the right to access corporate information in all countries according to EBRD (2017). In Bulgaria, the legislation requires public interest entities (such as publicly traded companies and banks) to create an audit committee, which is appointed by and reports to the general shareholders' meeting. It consists of "outsiders" (i.e., non-party members) and it cannot be categorized as a "board" committee properly (EBRD, 2017b).

In Serbia, the statute gives shareholders certain legal privileges regarding the general meeting of shareholders, as well as certain general safeguards and access to company records. Current shareholders can call a general shareholders' meeting, recommend the agenda of the general shareholders' meeting, appoint members, board members and launch a derivative lawsuit (EBRD, 2017h). In Slovenia, investors have no clear right to raise questions at the GSM (general shareholders' meeting) provided by the statute. It is only the Code of Corporate Governance which advises each member to be allowed to debate issues on the schedule, make inquiries and submit recommendations (EBRD, 2017g).

Table 11. Rights of shareholders in SEE countries

\begin{tabular}{lccccccccc}
\hline \multicolumn{1}{c}{ Key areas and rating } & AL & B\&H & BU & CR & MA & MO & SE & SL & KS \\
\hline $\begin{array}{l}\text { General shareholders' } \\
\text { meeting (GSM) }\end{array}$ & 4 & 4 & 4 & 4 & 4 & 4 & 4 & $3 / 4$ & 3 \\
\hline $\begin{array}{l}\text { Protection against insider } \\
\text { trading and self-dealing }\end{array}$ & 3 & 3 & 4 & 4 & $3 / 4$ & 3 & 3 & 3 & 2 \\
\hline $\begin{array}{l}\text { Minority shareholders } \\
\text { protection and shareholders' } \\
\text { access to information }\end{array}$ & 3 & $3 / 4$ & 4 & 3 & 4 & 3 & $3 / 4$ & $3 / 4$ & 3 \\
\hline Registration of shareholdings & 3 & 4 & 4 & 4 & 4 & 4 & 3 & 4 & 3 \\
\hline
\end{tabular}

Note: very weak - 1; weak - 2; fair - 3; moderately strong - 4; strong to very strong - 5 .

Source: Authors' summary using data from EBRD - Corporate governance in transition economies: Individual country reports (2017a 2017b, 2017c, 2017d, 2017e, 2017i, 2017f, 2017g, 2017h) 
Figure 5. Rights of shareholders in SEE countries

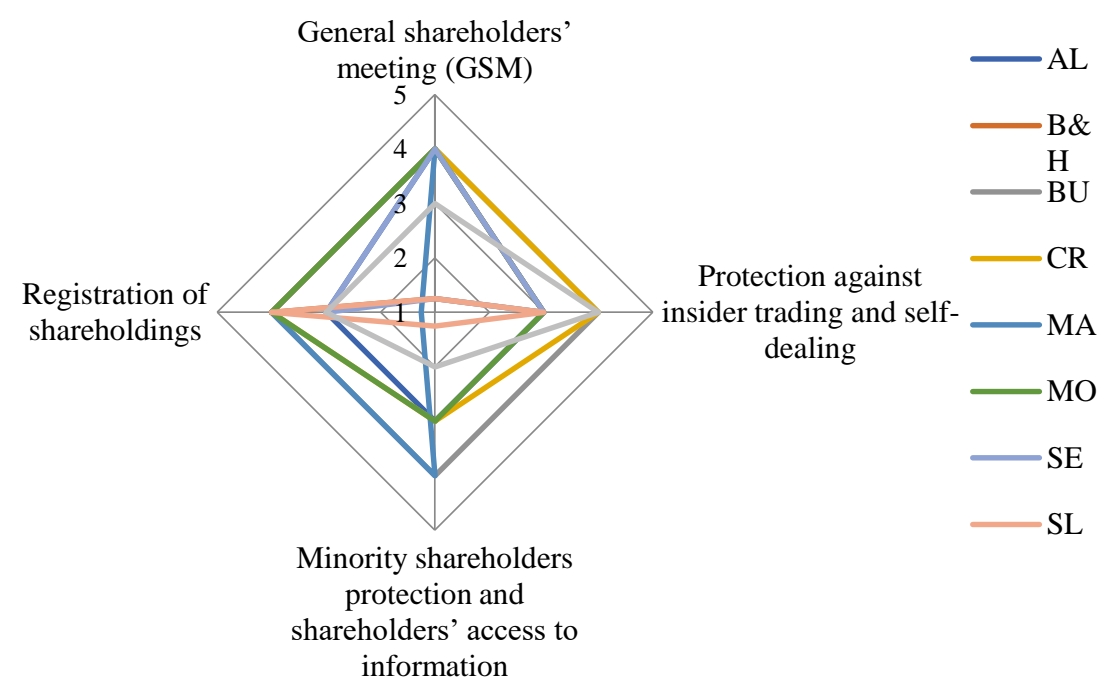

Source: Authors' summary using data from EBRD - Corporate governance in transition economies: Individual country reports (2017a 2017b, 2017c, 2017d, 2017e, 2017i, 2017f, 2017g, 2017h)

Shareholders in the Republic of Kosova shall have the ability to view main company documents and exercise pre-emptive privileges in the event of a capital increase. Simple shareholder protection is constitutional. Combined total voting is considered by law but may still be provided for in the Articles (EBRD, 2017e).

\subsection{Stakeholders and institutions}

In Albania, the stock exchange is closed. Regulatory agency rulings are documented in Albania and Bosnia and Herzegovina and are publicly available but not easily accessible. The presence of international audit firms is significant in the country; however, the presence of international law firms is limited. Global rating agencies in that country are not active (EBRD, 2017). According to EBRD (2017d), the governance structure which supports good corporate governance appears to be relatively sound in Croatia.

In North Macedonia, international law and rating firms have no significant presence, while international audit firms seem to be largely present (EBRD, 2017i). In Serbia, the organizational environment that promotes corporate governance seems to be fairly developed, but the advancement of current efforts would benefit from key reforms. Corporate governance legislation contains inconsistencies, while 
indicators from international organizations reveal that corruption is still perceived as a problem (EBRD, 2017h). According to EBRD (2017g), in Slovenia, only the Corporate Governance Code recommends that each shareholder should have the right to discuss items on the agenda, ask questions, and provide proposals.

Table 12. Stakeholders and institutions in SEE countries

\begin{tabular}{lccccccccc}
\hline Key areas and rating & AL & B\&H & BU & CR & MA & MO & SE & SL & KS \\
\hline $\begin{array}{l}\text { Corporate governance } \\
\text { structure and institutions }\end{array}$ & 2 & 3 & 3 & 3 & $3 / 2$ & 3 & $2 / 3$ & 4 & 3 \\
\hline $\begin{array}{l}\text { Corporate governance code } \\
\text { Institutional environment }\end{array}$ & 2 & 2 & 2 & 4 & 2 & $3 / 2$ & 2 & 4 & 2 \\
\hline
\end{tabular}

Note: very weak - 1; weak - 2; fair - 3; moderately strong - 4; strong to very strong - 5 .

Source: Authors' summary using data from EBRD - Corporate governance in transition economies: Individual country reports (2017a 2017b, 2017c, 2017d, 2017e, 2017i, 2017f, 2017g, 2017h)

\section{Figure 6. Stakeholders and institutions in SEE countries}

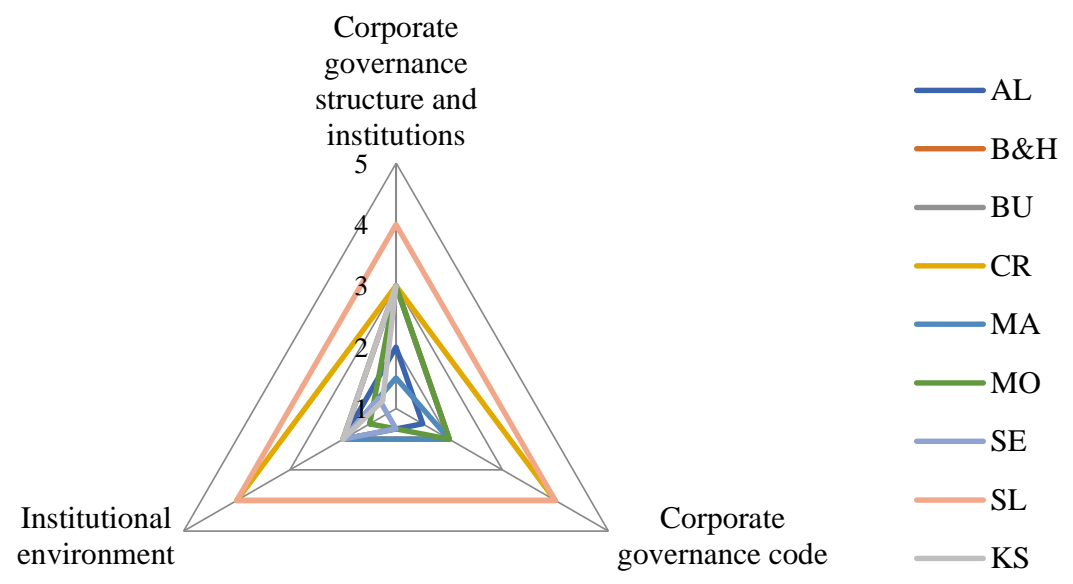

Source: Authors' summary using data from EBRD - Corporate governance in transition economies: Individual country reports (2017a 2017b, 2017c, 2017d, 2017e, 2017i, 2017f, 2017g, 2017h)

Shareholders in the Republic of Kosova do not have an indirect right to ask questions at the GSM granted by law. Only the Corporate Governance Code 
recommends that each shareholder should have the right to discuss items on the agenda, ask questions, and provide proposals. The indicators by international organizations show a framework where corruption is still perceived as a critical problem (EBRD, 2017e).

\section{Conclusion}

This paper provides an exploration of corporate governance from various perspectives. Corporate governance is a blanket term, which includes the managers, investors, and regulators within a business who exchange power, resources, and information. It aims to achieve an efficient allocation of resources and enhance the transparency of the information exchange between managers, the board of directors and shareholders. The business governance literature explores the efficacy of alternate management arrangements, the board members and several other governance mechanisms. Possibly, the best-managed corporate governance is often an important factor for promoting economic development and creating greater room for productive entrepreneurship. An effective board is important not only for its owners and creditors but also for the financial sector's growth. Sound financial institution governance is the requirement for safeguarding a country's financial intermediaries' health, as well as its economic and business development.

Based on this comparative analysis in SEE countries, Albania has the lowest scores compared with other countries. Meanwhile, Croatia and Slovenia have the highest scores for Corporate Governance Legislation and Practice.

A voluntary corporate governance code exists in Albania but it is generally not implemented. One of the banks has included a compliance statement in its annual report; however, the disclosure is still limited. There are a few contradictions in the legislation and certain stringent problems related to corporate governance are not controlled. International organizations' metrics indicate a system where abuse is often viewed as a serious problem. On the other hand, in Croatia, the Corporate Governance Code is an excellent addition to the legislation. A notice of conformity has been released by the ten top-listed firms. The authorities and the exchange have produced very interesting periodic data that offers a detailed summary of the role of corporate governance and corporate bond market conditions. The institutional framework which supports good corporate governance in Slovenia is also relatively advanced. The Ljubljana Stock Exchange (LJSE) is Slovenia's regulated market. Companies must submit a statement of compliance with the Corporate Governance Code and adhere to stricter disclosure practices to be listed as part of the Standard or Prime Market Segments.

Managers in all SEE countries should recognize corporate governance as one aspect of depositor security, providing banks with advice on good corporate governance and pro-active procedures, evaluate the execution of corporate governance practices by banks, evaluate the consistency of audit and control 
activities of banks, and assess the results of the group structure of the banks; also, any problems detected through supervisory efforts should be brought to the attention of boards and senior management.

\section{References}

Alihodžić, A. (2020), Sensitivity of bank profitability to changing in certain internal and external variables: the case of Bosnia and Herzegovina, Eastern Journal of European Studies, 11(2), pp. 182-202.

Arun, T.G. and Turner, J.D. (2004), Corporate governance of banks in developing economies: Concepts and issues, Corporate Governance: An International Review, 12(3), pp. 371-377.

Azarian, R. (2011), Potentials and limitations of comparative method in social science, International Journal of Humanities and Social Science, 1(4), pp. 113-125.

Basel Committee on Banking Supervision (2015), Guidelines: Corporate governance principles for banks.

Beju, D.G. and Ciupac-Ulici, M.L. (2012), The impact of financial liberalization on banking system, Procedia Economics and Finance, 3, pp. 792-799. https://doi.org/10.1016/S2212-5671(12)00232-8

Berglöf, E. and Pajuste, A. (2005), What do firms disclose and why? Enforcing corporate governance and transparency in Central and Eastern Europe, Oxford Review of Economic Policy, 21(2), pp. 178-197. https://doi.org/10.1093/oxrep/gri011

Bloom, D., Ratnikov, K.Y., Osipov, K.A. and Areshev, S.M. (2003), Corporate takeovers, Russian style, and necessary legal reform, Corporate Governance and Investment in Transitioning Economies, Boston.

Buşu, M. (2015), Corporate Governance Codes in Romania and European Union Countries, Revista de Management Comparat Internațional, 16(1), pp. 119-128.

Cigna, G.P. and Guy, M.L. (2012), Corporate governance for banks in Southeast Europe: Policy Brief, No. 70518, pp. 1-76, The World Bank, Washington DC (retrieved from http://documents.worldbank.org/curated/en/698701468032340335/Corporategovernance-for-banks-in-Southeast-Europe-policy-brief).

Çipi, A., Llaci, S. and Ferreira, F.A. (2014), Current situation of corporate governance practices in Albanian joint stock companies: a Delphi-based approach, ProcediaSocial and Behavioral Sciences, 110, pp. 841-851. https://doi.org/10.1016/j.sbspro.2013.12.929

Claessens, S. and Yurtoglu, B. (2012), Corporate governance and development: An update, World Bank.

De Andres, P. and Vallelado, E. (2008), Corporate governance in banking: The role of the board of directors, Journal of Banking \& Finance, 32(12), pp. 2570-2580. https://doi.org/10.1016/j.jbankfin.2008.05.008 
De Basilea, C. (2006), Enhancing corporate governance for banking organisations. (retrieved from https://www.bis.org/publ/bcbs122.pdf).

European Bank for Reconstruction and Development (2003), Transition Report 2003: Integration and Regional Cooperation (retrieved from https://www.ebrd.com/downloads/research/transition/TR03.pdf).

European Bank for Reconstruction and Development (EBRD) (2016), Corporate Governance for Banks in Southeast Europe (retrieved from https://www.ifc.org/wps/wcm/connect/cf5625004af270888657b7b94e6f4d75/SEE_ Banks_PolicyBrief.pdf?MOD=AJPERES).

European Bank for Reconstruction and Development (EBRD) (2017), Country Reports (retrieved from https:/www.ebrd.com/what-we-do/sectors/legal-reform/corporategovernance/sector-assessment.html).

European Bank for Reconstruction and Development (EBRD) (2017a), Corporate Governance in Transition Economies Albania Country Report (retrieved from https://www.ebrd.com/cs/Satellite?c=Content\&cid=1395251987830\&pagename=EB RD\%2FContent\%2FDownloadDocument).

European Bank for Reconstruction and Development (EBRD) (2017b), Corporate Governance in Transition Economies Bulgaria Country Report (retrieved from https://www.ebrd.com/cs/Satellite?c=Content\&cid=1395252167305\&pagename=EB RD\%2FContent\%2FDownloadDocument).

European Bank for Reconstruction and Development (EBRD) (2017c), Corporate Governance in Transition Economies Bosnia and Herzegovina Country Report (retrieved from https://www.ebrd.com/cs/Satellite?c=Content\&cid=1395252167175 \&pagename $=$ EBRD $\% 2$ FContent $\% 2$ FDownloadDocument).

European Bank for Reconstruction and Development (EBRD) (2017d), Corporate Governance in Transition Economies Croatia Country Report (retrieved from https://www.ebrd.com/cs/Satellite?c=Content\&cid=1395251705124\&pagename=EB RD\%2FContent\%2FDownloadDocument).

European Bank for Reconstruction and Development (EBRD) (2017e), Corporate Governance in Transition Economies Kosova Country Report (retrieved from https://www.ebrd.com/cs/Satellite?c=Content\&cid=1395251706580\&pagename=EB RD\%2FContent\%2FDownloadDocument).

European Bank for Reconstruction and Development (EBRD) (2017f), Corporate Governance in Transition Economies Montenegro Country Report (retrieved from https://www.ebrd.com/cs/Satellite?c=Content\&cid=1395251747378\&pagename=EB RD\%2FContent\%2FDownloadDocument).

European Bank for Reconstruction and Development (EBRD) (2017g), Corporate Governance in Transition Economies Slovenia Country Report (retrieved from https://www.ebrd.com/cs/Satellite?c=Content\&cid=1395252413881\&pagename=EB RD\%2FContent\%2FDownloadDocument).

European Bank for Reconstruction and Development (EBRD) (2017h), Corporate Governance in Transition Economies Serbia Country Report (retrieved from 
https://www.ebrd.com/cs/Satellite?c=Content\&cid=1395251747860\&pagename=EB RD\%2FContent\%2FDownloadDocument).

European Bank for Reconstruction and Development (EBRD) (2017i), Corporate Governance in Transition Economies Macedonia Country Report (retrieved from https://www.ebrd.com/cs/Satellite?c=Content\&cid=1395251705171\&pagename=EB RD\%2FContent\%2FDownloadDocument).

European Bank for Reconstruction and Development (EBRD) (2020), Corporate Governance of Banks - International Standard (retrieved from www.ebrd.com/whatwe-do/sectors/legal-reform/corporate-governance/international-standards.html).

Fox, M.B. and Heller, M.A. (2000), Corporate governance lessons from Russian enterprise fiascos, NYUL Rev., 75, p. 1720.

Gericke R.C. (2018), Corporate governance and risk management in financial institutions: An international comparison between Brazil and Germany: Springer.

Hopt, K.J. (2013), Better governance of financial institutions. Corporate Governance of Banks and Other Financial Institutions After the Financial Crisis, Journal of Corporate Law Studies, 13, pp. 219-253.

Landman, T. (2008), Issues and Methods in Comparative Politics: An Introduction, 3rd ed, London, New York: Routledge.

Levine, R. (2004), The corporate governance of banks: A concise discussion of concepts and evidence, The World Bank. https://doi.org/10.1596/1813-9450-3404

Lor, P.J. (2010), International and comparative librarianship, in: Encyclopedia of library and information sciences, Third Edition, Taylor and Francis: New York, pp. 2847-2855.

Macey, J.R. and O'Hara, M. (2003), The corporate governance of banks, Economic Policy Review, (Apr), pp. 91-107.

Mueller, D.C. and Peev, E. (2007), Corporate governance and investment in Central and Eastern Europe, Journal of Comparative Economics, 35(2), pp. 414-437. https://doi.org/10.1016/j.jce.2007.02.001

Oman, C.P. and Blume, D. (2005), Corporate Governance: A development challenge, Policy Insights \#3, OECD.

Organisation for Economic Co-operation and Development (2015), G20/OECD Principles of Corporate Governance (retrieved from https://www.oecd.org/ corporate/ca/Corporate-Governance-Principles-ENG.pdf)

Peev, E. (2002), Transition policy and corporate governance design in the 990: The case of Bulgaria, Paper presented at the 3rd Conference "Transition and Enterprise Restructuring in Eastern Europe, Copenhagen, 5-8 August”.

Peev, E. and Mueller, D.C. (2012), Democracy, economic freedom and growth in transition economies, Kyklos, 65(3), pp. 371-407.

Pervan, I. and Bartulović, M. (2014), Value relevance of accounting information: evidence from South Eastern European countries, Economic research-Ekonomskaistraživanja, 27(1), pp. 181-190. 
Rosenbaum, E., Bönker, F. and Wagener, H. (2000), Privatization, corporate governance and the emergence of markets, Springer.

Toçi, V. and Hashi, I. (2013), Intermediation Efficiency of Banks in South-East Europe, International Journal of Finance \& Banking Studies, 2(3), pp. 1-20. https://doi.org/10.20525/ijfbs.v2i3.151 